\title{
PERAN POLISI DALAM PERTAHANAN KEMERDEKAAN II TAHUN 1948-1949 DI SURAKARTA
}

\author{
Putri Indah Nur L, Djumarwan \\ Universitas Negeri Solo \\ Alamat korespondensi: putriindahnur@ymail.com
}

Diterima: 4 Desember 2018; Direvisi: 21 Januari 2019; Disetujui: 23 Januari 2019

\begin{abstract}
The arrival of Dutch to Indonesia after proclamation is not accepted by the people of Indonesia. This action implemented by the heroic insident in many places in Indonesia. This situation is getting worse with the Renville agreement has been cancelled and invasion Military Agression II by Dutch. Rebellion is doing by the people of Indonesia, including united police. The united police influences the defense military's strength and as their duties to look after the security. The purpose of the research is describing the condition of Surakarta during Japan's invasion to form organization of police in Surakarta and its role to face independence war II in Surakarta. This research uses method of critical history. This method starts from heuristics, sources, critical, interpretation, and historiography. Heuristic is steep of seeking and collecting data or sources and information about incident which has been analyzes. Sources critical is steep to study credibility of source by physicly and content. Interpretation is steep to seek the relation of meaning which has to do with the facts that have been received there for history incident to be clearer. Historiography is steep to write synthesis in form history piece. The result of this research shows Surakarta during Japan's invasion in 1942-1945 has goverment system that has been change by Japan, so it reveals the pioneer of Special Police (Tokubetsu Keisatsu Tai), also the involve revolutionary action police of Surakarta in independence of RI against Japan. The exsistence of police starts to evolve by forming police organization system in Surakarta. The unity its each region has structure in them. Surakarta police has function also as defense tool of nation. As military unity police role involve in extermination PKI in Madiun 1948 and Dutch military agression to in general attact for four days in Surakarta 1949. During the battle in Surakarta the police with another fighting unity against Dutch to face attact from land and air. This police unity is strengthened by forming Mobile Brigade residency (MBK) as implementation against Military Agression II, until Surakarta can take back from Netherland under authority of United Nations Commision for Indoensia (UNCI).
\end{abstract}

Keywords: Police; independence war II; Surakarta

\begin{abstract}
Abstrak
Kedatangan Belanda ke Indonesia pasca proklamasi ditentang oleh seluruh rakyat Indonesia. Aksi tersebut diwujudkan melalui peristiwa heroik di beberapa tempat di Indonesia. situasi diperparah dengan pembatalan perjanjian Renville dan serangan Agresi Militer ke II oleh pihak Belanda. Perlawanan dilakukan oleh seluruh rakyat Indonesia, tidak terkecuali kesatuan polisi. Berdirinya kepolisian berpengaruh pada kekuatan militer pertahanan dan sebagai tugas untuk menjaga keamanan. Tujuan penelitian ini adalah menguraikan kondisi Surakarta masa Jepang, pembentukan struktur organisasi Kepolisian Surakarta dan peranannya dalam menghadapi Perang Kemerdekaan II di Surakarta. Penelitian ini menggunakan metode penelitian sejarah kritis. Metode sejarah kritis dimulai dari heuristik, kritik sumber, interpretasi, dan historiografi. Heuristik merupakan tahap pencarian dan pengumpulan data atau sumber-sumber dan informasi mengenai peristiwa yang sedang diteliti. Kritik sumber merupakan tahap untuk mengkaji kredibilitas sumber-sumber yang diperoleh baik dari segi fisik maupun isi. Interpretasi merupakan tahap untuk mencari keterkaitan makna yang berhubungan antara fakta-fakta yang telah diperoleh sehingga peristiwa sejarah menjadi lebih jelas. Historiografi merupakan tahap penulisan sintesis dalam bentuk karya sejarah. Hasil penelitian menunjukkan Surakarta masa pendudukan Jepang tahun 1942-1945 memiliki sistem pemerintahan yang dirombak Jepang sehingga memunculkan cikal bakal Polisi Istimewa (Tokubetsu Keisatsu Tai), juga keterlibatan aksi revolusioner Polisi Surakarta dalam kemerdekaan RI melawan Jepang. Keberadaan polisi mulai berkembang dengan membentuk sistem organisasi polisi di Surakarta, kesatuan-kesatuan tiap daerah yang memiliki struktur bagian masing-masing daerah. Polisi Surakarta juga berfungsi sebagai alat pertahanan negara. Sebagai kesatuan militer peran polisi terlibat dalam aksi penumpasan PKI di Madiun 1948, dan Agresi Militer Belanda II dalam Serangan Umum Empat Hari di Surakarta tahun 1949. Selama pertempuran berlangsung di Surakarta polisi beserta kesatuan tempur lainnya melawan Belanda menghadapi serangan dari darat maupun udar. Kesatuan polisi diperkuat dengan mebentuk Mobile Brigade Karesidenan (MBK) sebagai wujud perlawanan Agresi Militer ke II, hingga Surakarta dapat direbut kembali dari pihak Belanda di bawah pengawasan United Nations Comission for Indonesia (UNCI).
\end{abstract}

Kata Kunci: Polisi; perang Kemerdekaan II; Surakarta 


\section{A. Pendahuluan}

Pada masa pendudukan Jepang, polisi sebagai alat perlengkapan pemerintah membantu usaha peperangan dan turut dalam pertahanan penjagaan dari serangan musuh. Penyelenggaraan keamanan dalam negeri juga ditujukan kepada usaha preventif. Segala sesuatu diurus oleh penguasa militer, tetapi ada bidang yang perlu diperhatikan oleh tentara pendudukan Jepang, yakni persoalan ketertiban dan keamanan masyarakat dari berbagai tidak pidana kriminal. Oleh karena itu, dibentuklah Pasukan Polisi Istimewa (Tokubetsu Keisatsu Tai) yang merupakan kesatuan berbobot tempur militer, sehingga polisi pada masa itu pun dilengkapi dengan senjata oleh tentara Jepang. Pada akhirnya, polisi menjadi suatu kekuatan penting dalam kekuatan tempur Indonesia di masa berikutnya. Polisi diperkuat dengan mantri polisi dan pamong praja karena pamong praja dimasukkan dalam dinas polisi. Berita kekalahan Jepang dalam Perang Asia Timur Raya mampu menumbuhkan semangat rakyat Indonesia melucuti tentara Jepang.

Setelah proklamasi Kemerdekaan Indonesia, 17 Agustus 1945, Kepolisian Indonesia memasuki sebuah era baru, yakni dapat mengatur sistem organisasi sendiri. Namun ini tidak dapat diartikan bahwa pada saat itu keadaan telah membaik sepenuhnya. Oleh karena itu, timbullah revolusi fisik untuk mempertahankan kemerdekaan Indonesia. Dalam situasi yang demikian, hampir seluruh wilayah di Indonesia mengalami kekacauan dan kecemasan yang membaur menjadi satu dengan pekik dan sorak-sorai kemerdekaan.

Seiring situasi keamanan nasional yang semakin mencekam, maka pemerintah pusat Presiden Soekarno pada tanggal 5 Oktober 1945, mengeluarkan dekrit berisi peleburan Badan Keamanan Rakyat (BKR) menjadi organisasi ketentaraan resmi yang bernama Tentara Keamanan Rakyat (TKR) (Sumantri, 1970: 43).

Surakarta sebagai salah satu kota penting dalam percaturan politik Indonesia, khususnya sejak awal abad kedua puluh, cukup rawan terhadap konflik.

Di kota ini juga terjadi aksi penculikan, bahkan kerusuhan seringkali terjadi. Oleh karena itu, revolusi yang terjadi pasca proklamasi tahun 1945, khususnya dalam bidang militer sangat berpengaruh besar pada kehidupan di Surakarta. Banyak pejabat terutama polisi dan pamong praja dari zaman kolonial Hindia Belanda menjadi korban masa awal revolusi fisik tersebut (Sumantri, 1961: 3).

Masa Perang Kemerdekaan II peran militer tersebut dipentingkan tidak hanya oleh TNI tetapi polisi juga bergerak untuk membela kemerdekaan Republik Indonesia. Perkembangan Kepolisian Surakarta pada masa revolusi cukup menarik untuk dilihat lebih jauh dalam perspektif sejarah. Berbagai peristiwa besar yang berskala nasional, dan juga internasional memberi pengaruh pada situasi dan kondisi Kepolisian Surakarta, baik sebagai institusi maupun alat negara. Dalam sejarah Indonesia, aspek militer menjadi bagian penting, namun polisi sepertinya tidak banyak disebutkan dengan baik, padahal konstribusi mereka cukup menentukan situasi dan kondisi suatu masyarakat.

Melalui Perjanjian Renville, terbentuklah negara federal di Indonesia yang kemudian mendapat pertentangan dari pihak republik. Pada situasi yang demikian, polisi (termasuk polisi di Surakarta) merupakan bagian 
dari perjuangan kemerdekaan sekaligus sebagai alat negara untuk menciptakan keamanan dan ketertiban di Surakarta. Keadaan Surakarta era Perang Kemerdekaan mengalami situasi mencekam. Dengan terbentuknya Polisi Surakarta berperan penting dalam mempertahankan Kemerdekaan RI dari serangan Agresi Militer 1948-1949 di Surakarta khususunya. Kondisi kota Surakarta yang sangat kompleks dengan peristiwa PKI Madiun 1948 juga berdampak pada keutuhan negara. Polisi Surakarta menjadi bagian terpenting dari masa revolusi di Jawa Tengah. Tidak hanya persoalan dengan Belanda, tetapi juga dengan Peristiwa Madiun 1948. Polisi Surakarta mengambil bagian sebagai alat negara untuk menciptakan keamanan dan ketertiban dalam masyarakat.

\section{B. Metode Penelitian}

Penulisan sejarah sebagai ilmu memiliki sebuah metod tersendiri yang menggunakan pengamatan dan penyelidikan. Jika suatu pernyataan tidak didukung oleh bukti-bukti sejarah maka pernyataan itu ditolak (Kuntowijoyo, 2005: 64). Metode bertujuan untuk mengkaji lebih dalam mengenai suatu peristiwa dengan berbagai perangkat analisis supaya dapat diketahui penyebab mengapa suatu peristiwa itu terjadi. Menurut Louis Gottscalk metode sajarah terdapat empat tahapan yaitu, heuristik, verifikasi, interpretasi (penafsiran) dan historiografi. Sehingga metode dalam penelitian ini yaitu:

1. Heuristik

Heuristik yang mempunyai arti pengetahuan tentang penyelidikan sumber sejarah. Data sejarah atau sumber sejarah menurut bahannya dapat dibagi menjadi dua: tertulis dan tidak tertulis, atau dokumen dan artifact (artefak) (Kuntowijoyo, 2005: 64; Purwantana, 2002: 31-32).

Sementara, berdasarkan fungsinya, sumber sejarah terbagi menjadi sumber primer dan sumber sekunder. Sumber primer adalah sumber yang berasal dari tangan pertama. Sumber jenis ini dapat berupa arsip, catatan harian, saksi mata, atau dokumen resmi pemerintah, dan foto. Sementara, sumber sekunder merupakan sumber yang tidak berasal dari waktu kejadian. Sumber ini biasanya berupa buku-buku yang ditulis seorang sejarawan terhadap suatu peristiwa sejarah.

Selain itu, sumber sekunder berupa buku-buku, artikel, jurnal, dll yang terkait dengan penelitian juga akan dipakai dalam penelitian ini. Pengumpulan sumber tersebut dilakukan di perpustakaan pusat UNY, Laboratorium Jurusan Pendidikan Sejarah UNY, Perpustakaan Fakultas Ilmu Budaya UGM, Perpustakaan Pusat UGM, Perpustakaan Fakultas Ilmu Budaya UNS, Perpustakaan Arsip Nasional Republik Indonesia (ANRI), Perpustakaan pusat sejarah ABRI , Perpustakaan Markas Besar POLRI, Arsip Nasional Republik Indonesia (ANRI), Perpustakaan Nasional Republik Indonesia dan Balai Pelestarian Nilai Budaya (BPNB) Yogyakarta.

\section{Verivikasi}

Kritik sumber atau verifikasi adalah suatu proses pengujian dan analisa secara kritis dan objektif supaya dapat dibuktikan kebenaran dan kelalaian dari sumber-sumber yang berhasil dikumpulkan. Kritik sumber terdiri dari kritik ekstern dan kritik intern. Kritik ekstern yaitu pengujian otentitas (keaslian) data, turunan, palsu, serta relevan atau tidaknya suatu sumber. Tujuan dari kritik ekstern adalah untuk mengetahui apakah sumber pada suatu 
waktu sejak awal mulanya sumber itu telah diubah atau tidak (Sjamsudin, 2007: 134). Kritik intern merupakan kritik terhadap isi sumber yang bertujuan untuk membuktikan apakah kesaksian dan pernyataan sumber dapat diandalkan atau tidak (Kuntowijoyo, 2005: 101). Kritik intern digunakan untuk mengetahui validitas isi sumber. Kritik ini merupakan pemeriksaan terhadap isi sumber yang bertujuan untuk membuktikan apakah kesekian pernyataan sumber dapat diandalkan atau tidak.

3. Interpretasi

Interpretasi merupakan penafsiran yang dilakukan oleh seorang sejarawan terhadap data-data yang sudah terseleksi. Seorang sejarawan menafsirkan supaya suatu peristiwa dapat dimengerti dan dipahami oleh pembaca. Interpretasi mencakup analisis dan sistesis. Analisis merupakan proses penyelidikan terhadap suatu peristiwa untuk mengetahui keadaan yang sebenarnya, sebab-musabab dari sebuah peristiwa. Analisis dilakukan dengan cara menguraikan suatu pokok atas berbagai bagiannya dan penelaahan bagian itu sendiri serta hubungan antarbagian untuk memperoleh pengertian yang tepat dan pemahaman arti secara keseluruhan. Proses analisis akan menghasilkan fakta-fakta yang kemudian disintesiskan, yaitu menyatukan atau mengelompokkan data-data yang saling keterkaitan antara fakta yang satu dengan fakta yang lain sehingga menjadi satu kesatuan (Kuntowijoyo, 2005: 102-103).

4. Historiografi

Historiografi merupakan tahap akhir dalam penelitian sejarah. Penyusunan data-data yang telah menjadi fakta-fakta sejarah yang diperoleh dari penelitian kemudian direkonstruksi menjadi sebuah peristiwa sejarah. Hasil penafsiran yang diperoleh kemudian dituliskan secara kronologi dalam bentuk tulisan sejarah. Penulisan sejarah ini dilakukan dengan model penulisan sejarah analisis. Sejarah analitis merupakan sejarah yang berpusat pada pokok permasalahan. Berbagai permasalahan kemudian akan diuraikan secara sistematis, dengan titik berat pada permasalahan inilah sejarah analitis memerlukan bantuan ilmu-ilmu sosial dalam kajiannya (Kartodirdjo, 1993: 9).

\section{Pendekatan Penelitian}

Proses rekonstruksi sejarah mengenai suatu peristiwa sejarah sangat tergantung pada pendekatan yang dilakukan dalam penelitian. Pendekatan penelitian untuk memperjelas dan mempertajam kajian masalah. Dalam penulisan sejarah diperlukan teori-teori dari disiplin ilmu yang memiliki penjelasan lebih baik untuk menganalisis sejarah. Berdasarkan hal tersebut, maka penulis menggunakan beberapa pendekatan sebagai analisis dari penelitian ini. Pendekatan yang digunakan adalah pendekatan sosiologi, militer, ekonomi dan politik.

1) Pendekatan Sosiologi

Pendekatan sosiologi adalah suatu pendekatan yang menyelidiki persoalan umum dalam masyarakat dengan maksud untuk menemukan dan menafsirkan kenyataan-kenyataan dalam kehidupan masyarakat atau berusaha memahami kekuatan-kekuatan dasar yang berada dibelakang tata kelakuan sosial (Kartodirdjo, 1993: 9). Teori yang digunakan untuk penelitian ini ialah teori yang diungkapkan oleh Bellamy. Teori tersebut menyatakan bahwa elite merupakan orang atau sekelompok orang yang memegang posisi terkemuka dalam suatu 
masyarakat (Richard, 1990: 9). Pola hubungan elite tidak hanya memposisikan dirinya diatas anggota masyarakat tetapi sekaligus berusaha mempertahankan statusnya (Kartodirdjo, 1993: 40).

Pendekatan sosiologi membantu mengungkap unsur-unsur sosial dalam suatu deskripsi, seperti struktur sosial, sistem politik, jaringan interaksi, struktur organisasi, pola kekuasaan atau pola perilaku dan lain sebagainya. Mobilitas sosial yang diterapkan sistem pemerintahan Jepang dan interaksi masyarakat pada masa itu. Di Surakarta pada masa Perang kemerdekaan II tahun 1948-1949 melibatkan rakyat Surakarta dengan Belanda. Menganalisis interaksi sosial terhadap hubungan sosial antara rakyat Surakarta dan polisi, hubungan sosial antara rakyat dan pemerintah.

\section{2) Pendekatan Militer}

Pendekatan militer ialah kebijakan pemerintah mengenai persiapan dan strategi militer yang menentukan potensi kekuatan perang negara sangat dipentingkan dengan berpedoman pada teori gerilya milik Abdul Haris Nasution ketika Perang kemerdekaan II polisi juga menggunakan strategi yang terstruktur dan memperkuat organisasi dengan membentuk detasemen atau batalyon dan diperkuat pada tiap-tiap rayon. Pendekatan militer digunakan sebagai taktik gerilya yang dibentuk antara pihak TNI maupun polisi sebagai peninjau melakukan serangan terhadap musuh. Peneliti dapat melihat aktivitas militer yang terjadi di Surakarta masa Perang Kemerdekaan II tahun 1948 1949.

\section{3) Pendekatan Ekonomi}

Pendekatan ekonomi digunakan untuk memecahkan masalah-masalah maupun dampak ekonomi sesuai dengan prinsip-prinsip dasar ekonomi.
Ilmu ekonomi digunakan untuk melihat keadaan ekonomi masayarakat Surukarta umumnya selain itu juga melihat keadaan ekonomi yang melatar belakangi sebagai kegiatan para gerilyawan untuk mendapatkan persenjataan amunisi dan dana kesehatan yang berguna melancarkan aksi Perang Kemerdekaan II di Surakarta untuk memperebutkan Indonesia dari tangan penjajah. Masa Perang Kemerdekaan II di Surakarta berpengaruh juga pada keadaan ekonomi secara langsung yang dialami oleh Masyarakat Surakarta. Serta akibat adanya PKI di Madiun 1948 yang mengacaukan Kota Surakarta banyak melakukan aksi pencurian, kejahatan dan perampokan.

4) Pendekatan Politik

Sejarah identik dengan politik, jika keduanya menunjukan proses yang mencakup keterlibatan para aktor dalam interaksinya serta peranannya dalam usahanya memperoleh "apa, kapan, dan bagaimana” (Kartodirdjo, 1993: 49). Pendekatan politik ini digunakan untuk mengkaji apa, kapan dan bagaimana politik yang terjadi masa Perang Kemerdekaan II di Surakarta tahun 1948-1949, saat itu Belanda melanggar perjanjian Linggarjati yang telah disepakati pihak Indonesia tetapi dengan jalur diplomasi tersebut Belanda melawan hingga memunculkan perang Kemerdekaan II tahun 1948-1949.

\section{Pembahasan}

\section{Keadaan Surakarta Tahun 1942- 1945}

A. Surakarta Masa Pendudukan

$$
\text { Jepang }
$$

Surakarta merupakan bagian Vorstenlandaen yaitu daerah wilayah Hindia Belanda yang memiliki status khusus. Luas keseluruhan Karesidenan Surakarta diperkirakan seluas 6.217 
$\mathrm{km}^{2}$ dari pusat Kota Surakarta (Ratna Nurhajarini, 2011: 260). Surakarta tidak bisa dipisahkan pada pusat kebudayaan tradisional Jawa. Kota Surakarta terbagi atas kekuasaan Kasunanan Surakarta dan Mangkunegaran.

Pada tanggal 5 Maret 1942 pasukan Jepang mulai menduduki daerah pedalaman Jawa salah satunya di wilayah Surakarta. Jepang lebih mementingkan kekuatan militernya yang dipimpin oleh Komandan Funabiki. Kehadiran pasukan Jepang ke Surakarta dihadang oleh pasukan Koninklijk Nederlands Indische Leger (KNIL), Batalyon Legiun Mangkunegaran, dan beberapa pasukan milisi. Penghadangan terhadap Jepang dengan tujuan untuk memperlambat gerak Jepang. Pada masa pendudukan Jepang perubahan tata pemerintahan daerah yang diatur dalam Undang-undang No. 27 Tahun 1942 menyangkut perubahanperubahan keorganisasian pemerintahan daerah bahwa seluruhnya Jawa kecuali Vorstenlanden terbagi atas karesidenan (shu), kotapraja (si), kabupaten (ken), distrik (gun), onder distrik (son), kelurahan (ku) (Soeratman, 1989: 2). Pemerintahan Jepang menawarkan pola mobilitas sosial baru bagi penduduk bumiputra, melalui pembentukan kelompok militer dan semi militer. Seperti Heiho, Keibodan, Seinendan dan Pembela Tanah Air (PETA) yang telah membentuk pemuda dan keluarganya memiliki status sosial yang baru (Purwanto, 2000: 142).

\section{B. Polisi Jepang}

Tugas polisi masa Jepang juga disesuaikan dengan kepentingan untuk melawan sekutu dan diarahkan untuk mencegah kejahatan-kejahatan yang berkaitan dengan pertahanan maupun kepentingan kekuasaan Jepang di Indonesia. Oleh karena itu, tugas polisi diarahkan pada pemberantasan dan pencegahan terhadap gerakan anti kekuasaan pemerintah Jepang. Selain polisi juga memiliki departemen tersendiri, dengan tanggung jawab atas keamanan dan ketertiban umum di daerah-daerah yang dikuasi oleh angkatan bersenjata Jepang yaitu Kempetai atau Polisi Militer yang merupakan dari bagian pasukan Angkatan Darat. Pada awal masa pendudukan Jepang Kempetai hanya aktif menangkap orang-orang yang membuat situasi menjadi kacau dalam kurun waktu beberapa bulan terakhir menjelang disintegrasi umum. Tugas utama mereka adalah mengumpulkan informasi rahasia dari penduduk dan meneruskannya ke kalangan pemerintah yang lebih tinggi. Kegiatan polisi meningkat hanya sesudah terjadinya perampokan kecil-kecilan, korupsi, dan pasar gelap menjadi ramai. Keadaan diperparah bersamaan dengan memburuknya perekonomian dan dikenakannya peraturan yang ketat (Nagazumi, 1998: 7).

Polisi masa Jepang juga terlibat kegiatan pengendalian ekonomi toseikeizai melalui pengumuman masyarakat peraturan ekonomi, hargaharga, dan larangan pengangkutan barang. Tiap-tiap shu pengendalian dilakukan oleh bagian ekonomi kantor shu. Administrasi kepolisian masa Jepang hampir sama dasarnya dengan sistem administrasi yang berlaku masa Hindia Belanda. Hanya saja sistem kepolisian yang diterapkan masa Hindia Belanda dihapuskan oleh Jepang. Tindakan-tindakan Belanda juga mempengaruhi pribumi secara tidak langsung menumbuhkan rasa nasionalisme akibat pemerintahan Jepang yang menyulitkan masyarakat 
pribumi. Karesidenan Surakarta melatih anggota Polisi Istimewa (Tokubetsu Keisatsu Tai) secara rutin dengan baris-berbaris yang dilakukan setiap pagi hingga sore hari, latihan beladiri dan perang-perangan. Hal itu dilakukan sebagai tenaga tempur apabila pemerintah militer Jepang menginginkan sebagai tenaga cadangan polisi. Pendidikan kader polisi diikuti oleh kader-kader polisi dari berbagai kesatuan di wilayah Jawa, pendidikan tersebut berlangsung selama tiga bulan.

C. Aksi Revolusioner

Kemerdekaan Republik

Indonesia

Pada tanggal 17 Agustus 1945 merupakan momen sejarah bagi rakyat Indonesia yang tidak pernah dilupakan oleh bangsa. Polisi juga menunjukkan peran aktif dalam aksi revolusioner di Surakarta dan merebut kekuasaan dari tentara Jepang di beberapa daerah. Sebagai pelopor militan di dalam aksi penurunan bendera Hinomaru dari tangan penguasa Jepang. Di Surakarta beberapa aksi revolusioner yang dilakukan oleh pemuda pejuang revolusi merebut kekuasaan Jepang di Surakarta antara lain Jawatan Radio Surakarta (Solo Hosoo Kyuku), Jawatan Pos, telegraf dan telepon (Surakarta Yubin, Densin dan Denwa Kyoku), Dinas Kepolisian Kota (Surakarta Keisatsu), Kantor Kepolisian Kota (Ciangbu),dan Jawatan Kereta api.

\section{Terbentuknya Kepolisian di Surakarta}

A. Organisasi Polisi di Surakarta.

Kantor kepolisian tertinggi di Surakarta adalah Polisi Karesidenan Surakarta (Surakarta Syu Chiangbu), kemudian polisi karesidenan tersebut membawahi Keisatsu. Syu atau kantorkantor Kepolisian Karesidienan Surakarta dan Surakarta Syu Tokubetsu Keisatsutai atau Pasukan Polisi Istimewa
Karesidenan Surakarta. Tugas kepolisian diperlancar dengan pembentukan organisasi polisi yang otonom pada tanggal 26 Juni 1946 pemerintah mengeluarkan penetapan No 11/SD tahun 1946 yang menempatkan Kepolisian Negara RI ke luar dari Kementrian Dalam Negeri dan menjadi lembaga tersendiri di bawah perintah langsung Perdana Menteri (Ibrahim, 2004: 119). Setelah Kemerdekaan Indonesia Kepolisian Surakarta tahun 1947 hingga tahun 1950 dikenal dengan nama Komawil (komando wilayah).

Seiring perkembangan zaman kemudian diganti menjadi Polwil (kepolisian wilayah) dengan tingkat wilayah kepolisian yang berada di kotamadya. Kepolisian Surakarta dengan pimpinan pejabat pada periode 1945-1959 yaitu Jendral Polisi R.M Said Soekanto Tjokrodiatmojo.

Perkembangan

organisasi

Kepolisian Karesidenan Surakarta pada tanggal 31 Agustus 1948 membentuk organisasi kepolisian. Berikut daerah yang mencakup Karesidenan Surakarta yaitu, Kabupaten Sragen, Kabupaten Boyolali, Kabupaten Sukoharjo, Kabupaten Klaten, Kabupaten Wonogiri, Kabupaten Karanganyar. Daerah Kepolisian Karesidenan Surakarta memiliki 3 seksi dan 7 kantor cabang polisi (randdetachementen) (Arsip Kepolisian Negara 1947-1949, No. 72).

Militerisasi Kepolisian Negara RI Instruksi militerisasi tersebut pada hakekatnya adalah penegasan secara administratif instrumental, karena secara praktis polisi melaksanakan tugas-tugas militer sejak awal proklamasi (Kartopati, 1967: 70).

Barisan pemuda didikan Jepang berusaha mengambil alih senjata dengan melucuti tentara sekutu. Persatuan dan kesatuan pemuda 
berkobar melalui usaha-usaha yang dilakukakn bahkan resiko pejuang tidak dipedulikan melalui satu tujuan yaitu mengusir penjajah dari bumi pertiwi. Ada berbagai nama serta kesatuan-kesatuan polisi antara lain, Pasukan Polisi Istimewa, Persatuan Polisi Perjuangan, dan Barisan Istimewa Polisi (Priyono, 1950: 16).

Sesuai instruksi yang disusun oleh Dewan Pertahanan Negara No. 13 menetapkan bahwa pimpinan tentara setelah mendengar pertimbangan dari Kepala Polisi Karesidenan atau Kepala Mobil Brigade dan Dewan Pertahanan Daerah menetapkan, kekuatan Mobile Brigade yang akan menjalankan kewajiban kepolisian di garis belakang, yang tidak boleh kurang dari dua pertiga dari kekuatan Mobile Brigade (Fadlullah, 1997: 102).

Setiap wilayah dipantau oleh Kepala Polisi Karesidenan dan Kepala Mobil Brigade dengan melihat keadaan dan kedudukan anggota Mobil Brigade yang menjalankan tugasnya. C. Kesatuan-Kesatuan Polisi di Surakarta Kepolisan di Indonesia menjelang proklamasi kemerdekaan 17 Agustus 1945 merupakan wadah organisasi bentukan dari pemerintah Jepang pimpinan Jendral Itagaki Seissairo. Usaha menyempurnakan Pasukan Polisi Istimewa, pada waktu itu masih ada sebutan kesatuan pasukan Polisi Istimewa, Persatuan Polisi Perjuangan dan Barisan Istimewa Polisi. Komisaris Polisi TK. I Soemarto sebagai Wakil Kepala Kepolisian Negara memiliki ide agar pasukan Polisi Istimewa diubah menjadi Mobile Brigade dengan pertimbangan menjadi kesatuan polisi yang memiliki kekompakan, disiplin, tinggi dan memiliki gerak cepat. Berdasarkan Surat Perintah Kepala Muda Kepolisian No. Pol: 12/78/91 sejak tanggal 14 November 1946 secara resmi Mobil Brigade telah lahir (Supomo, dkk, 1996: 23).

Kesatuan-kesatuan Mobile Brigade Karesidenan (MBK) saat itu dibentuk dengan kekuatan satu kompi dan sebagai komandan kompi memiliki pangkat yaitu Inspektur Polisi (IP) satu dan dua. Selain kesatuan MBK dibentuk pula Mobile Brigade Besar (MBB) yang menempati wilayah provinsi dan sebagai pusatnya Mobile Brigade Besar Jawatan Kepolisian Negara (MBB-DKN) dengan pimpinan satu Batalyon. Segenap kesatuankesatuan perjuangan Kepolisian RI menggunakan nama sebutannya masing-masing dengan melaksanakan atau melakukan reorganisasi, mempersiapkan anggota-anggota kesatuan kepolisian baik fisik maupun mental untuk menghadapi tugas di garis belakang atau front-front dengan tujuan menggempur musuh tentara Belanda. ${ }^{1}$

\section{Polisi dan Perang Kemerdekaan II di Surakarta}

a) Penumpasan PKI di Madiun

Pada tanggal 8 September 1948, PKI pimpinan Musso mengadakan perebutan kekuasaan di Madiun sebagai langkah pertama merebut kekuasaan Negara RI. Kekuatan bersenjata melawan PKI terdiri dari Brigade 29 yang berjumlah Batalyon 2 Brigade dan kesatuan-kesatuan lain dari wilayah Surakarta. Situasi Surakarta yang memanas disertai dengan pembunuhan dan penculikan Komandan Divisi Surakarta Dr. Muwardi pada tanggal 13 September 1948 terjadi peristiwa penyerangan markas Batalyon Siliwangi di Srambatan oleh pasukan yang

\footnotetext{
${ }^{1}$ Peristiwa penculikan Dr. Muwardi terjadi pada pukul 11.30 di rumah sakit Jebres yang sekarang menjadi RS Dr. Muwardi bahwa Dr. Muwardi ditodong oleh orang tak dikenal kemudian memaksananya masuk ke mobil (Ibrahim, 2004: 211)
} 
berhaluan kiri dan menewaskan 14 orang (Supomo, dkk, 1996: 91).

Mengingat Surakarta keadaannya semakin kacau dan banyak terjadi aksi kerusuhan sehingga Jawatan Kepolisian Negara RI memberikan instruksi gerakan serentak kepada anggotaanggotanya. Gerakan dilakukan pada tanggal 28 September 1948 melalui pemeriksaan semua rumah yang ada di dalam lingkungan dan diperiksa oleh Polisi Negara (ANRI, Kepolisian Negara RI 1947-1949, No. 06). Gerakan pemeriksaan pihak polisi menurunkan personil yaitu 6 Komisaris Polisi, 29 Inspektur Polisi, 18 Pembantu Inspektur Polisi, 40 Komandan Polisi dan 250 Agen. Pada akhirnya Madiun jatuh oleh pemerintahan Soekarno yang menyerukan kepada seluruh rakyat Indonesia bahwa PKI di Madiun berhasil ditumpas oleh militer.

b) Polisi dalam Agresi Militer Belanda II Agresi Belanda merupakan perpecahan dan keretakan yang ada di dalam tubuh pemerintahan Republik Indonesia sebagai akibat peristiwa Madiun dan bisa dibangun hingga potensi nasional pulih kembali. Banyaknya tawanan akibat peristiwa tersebut dapat kembali bersatu dengan tenaga nasional dan menunjukkan sebagai pejuang kemerdekaan RI. Pada tanggal 20 Desember 1948 pasukan Belanda memasuki daerah Surakarta. Komandan Brigade V Letnan Kolonel Slamet Riyadi mengeluarkan perintah bahwa pada pukul 18.00 WIB dimulai pembumi hangusan dan jembatanjembatan yang berada di dalam Kota Surakarta. Bunyi tembakan dan bom tanda dimulainya perang melawan Belanda. Sebagai pelopor pertama bom diledakkan oleh Vennieling-corps Tentara Pelajar dengan sasaran utama yaitu kantor Gubernur, Pasar Gede, Asrama Tentara Pelajar, Gedung Gajah
Staf Divisi IV Timuran dan kantor pos (Panitia Seksi Penggali Sejarah Monumen Sejarah Militer DAM VII/DIPONEGORO, 1965: 19).

Pada tanggal 22 Desember 1948 Mayor Achmadi mengadakan konsolidasi di Jumantoro membentuk Komando Daerah Solo (KDS) dengan membagi pasukan ke dalam rayonrayon. Medio satu bulan TNI bersama polisi dan rakyat berhasil melakukan konsolidasi pukulan-pukulan terhadap Belanda. Pertama kali yang menjadi sasaran adalah garis-garis komunikasi Belanda. Kawat-kawat telepon diputus, jalur kereta api dirusak, dan konvoikonvoi Belanda si siang hari diserang. Sebagai bentuk pertahanan pemerintahan militer RI pada tanggal 15 Mei 1949 membentuk alat kepolisian dengan nama Polisi Pemerintahan Militer (PPM) yang merupakan penggabungan dari Polisi Negara dan Corps Pemerintahan Militer (CPM). ${ }^{28}$ Tiap-tiap Komando Distrik Militer (KDM) mempunyai bagian-bagian oraganisai yang tersusun, sedangkan Komandan Detasemen dipimpin oleh pegawai polisi atau anggota CPM yang tertinggi pangkatnya (Panitia Seksi Penggali Sejarah Monumen Sejarah Militer DAM VII/DIPONEGORO, 1965: 75-76).

Semasa Agresi Militer Belanda II melakukan perlawanan menjelang diberlakukannya perintah penghentian tembak-menembak antara RI dan Belanda.

c. Serangan Umum Empat Hari di Surakarta

Pada tanggal 3 Agustus 1949 telah tercapai persetujuan antara pemerintah RI dengan Belanda mengenai penghentian permusuhan dan pelaksanaan case fire yang berlaku pada tanggal 11 Agustus 1949. Serangan umum terhadap Kota Surakarta terjadi 
dua gelombang, yaitu gelombang pertama tanggal 7-9 Agustus 1949, gelombang kedua pada tanggal 10 Agustus 1949. Melalui perintah Letnan Kolonel Slamet Riyadi (Pusjarah TNI, 2000: 212).

Instruksi Letnan Kolonel Slamet Riyadi memiliki tujuan untuk memperkuat dukungan fisik dan mental terhadap kesatuan-kesatuan yang berada di dalam wilayah Komando SWK (Sub Wehrkreise) I06, kesatuan Mobile Brigade Karesidenan (MBK) dan Tentara Pelajar 2 Kompi Mobrig yaitu Kompi Mobile Brigade Besar Djawatan Kepolisian Negara (MBB-DKN) di bawah pimpinan P.I.P. Bakir yang bermarkas di Sarwakan Madyo Taman dan Kompi Mobile Brigade Karesidenan (MBK) Surakarta pimpinan P.I.P. Mulyono bermarkas di Batangan, Mangkudiningrat Ikut dalam serangan di dalam Kota Surakarta. Sasaran utama peyerangan adalah pospos Belanda ada di luar Kota Surakarta dan kedudukan Belanda yang berlingkup menguasi Kota Surakarta. Pasukan polisi yang mengikuti serangan umum sebagai berikut (Supomo, dkk, 1996: 110; Santosa, 2009: 213-214).

1. Mobile Brigade Besar (MBB) di bawah komando Komisaris Utomo yang berkekuatan 100 orang dengan posisi di Rayon III.

2. Mobile Brigade Karesidenan (MBK) berkekuatan 100 orang dengan posisi di Rayon II dan kurang lebih 70 orang pasukan di Rayon I.

Pertempuran berlangsung 4 hari 4 malam hingga mencapai puncaknya pada tanggal 10 Agustus 1949, saat dilaksanakan serangan gelombang kedua. Sebagai sasarannya adalah semua obyek musuh di Kota Surakarta. Serangan ini tidak dimaksudkan untuk merebut kota, tetapi semata-mata untuk memberikan kesan kepada musuh bahwa TNI maupun polisi masih tetap kuat. Pada tanggal 24 Agustus 1949, Komando Kota Surakarta oleh Letnan Kolonel Slamet Riyadi diserahkan kepada Mayor Achmadi dan selanjutnya diadakan perundingan dengan pihak Belanda di bawah pengawasan United Nations Commision for Indonesia (UNCI) (Pusjarah TNI, 2000: 213-214)

\section{Kesimpulan}

Kondisi Surakarta era Agresi Militer Belanda II tahun 1948-1949 mengalami kekacauan khususnya di Kota Surakarta dan berdampak di wilayah Indonesia pada umumnya. Terbentuknya Polisi Istimewa yang melibatkan anggota tentara pelajar menjadi hal yang sangat penting untuk memperjuangkan Kemerdekaan RI. Menarik periode waktu era pendudukan Jepang, polisi terbentuk semakin kuat dengan didikan militer yang diterapkan. Terbentuknya organisasi Polisi Istimewa (Tokubetsu Keisatsu Tai) di Indonesia didominasi oleh kaum penjajah yakni Belanda dan Jepang dengan disesuikan kepentingan penjajah masing-masing. Keberadaan Polisi Surakarta menjadi salah satu bagian untuk mewujudkan tujuan utama Jepang yaitu Perang Asia Timur Raya. Pembentukan Polisi Istimewa (Tokubetsu Keisatsu Tai) mengawali lahirnya kesatuan militer yang terlibat dalam pelucutan senjata di tangsi militer Jepang. Berdirinya Polisi Istimewa (Tokubetsu Keisatsu Tai) mengalami perkembangan salah satunya tiap karesidenan seluruh Jawa-Madura dengan fasilitas senjata yang lebih lengkap.

Terbentuknya kepolisian Indonesia di bawah ketetapan Panitia Persiapan Kemerdekaan tanggal 19 Agustus 1945 termasuk dalam lingkungan Departemen Dalam Negeri. Jawatan 
Kepolisian RI dipimpin oleh Raden Said Soekanto Tjokrodiatmodjo. Pembentukan organisasi polisi diikuti tiap karesidenan. Struktur organisasi polisi pada bagian teratas dipimpin oleh Perdana Menteri kemudian disusun pada tiap-tiap bagian yaitu tata usaha, keuangan, perlengkapan, organisasi PAM (Pengawas Aliran Masyarakat), tata usaha dan kriminal. Kemudian Kepala Karesidenan terdiri dari bagian umum, PAM dan kriminal. Wilayah Karesidenan Surakarta terdiri dari Kabupaten Wonogiri, Klaten, Sukoharjo, Wonogiri, Boyolali, Karanganyar dan Kota Surakarta.

Tugas polisi berpegang teguh pada undang-undang negara dan peraturan pemerintah. Perkembangan selanjutnya polisi memiliki kesatuan-kesatuan yaitu Pasukan Polisi Istimewa, Persatuan Polisi Perjuangan dan Barisan Polisi Istimewa. Kesatuan polisi melebur dalam militerisasi Kesatuan Kepolisian Negara RI. Pada tanggal 14 November 1946 secara resmi Mobile Brigade lahir yang terhimpun dalam kesatuan Mobile Brigade Karesidenan (MBK) dengan pusatnya Mobile Brigade Besar Djawatan Kepolisian Negara (MBBDKN).

Tahun 1948 di Surakarta terjadi kekacauan yang mengakibatkan perpecahan politik antara pihak Amir Syarifuddin dan Mohammad Hatta. Salah satunya Surakarta sebagai proyek PKI dengan Sasaran utama yang dijadikan sebagai basis PKI ialah daerah Madiun yang dinilai sebagai daerah strategis dan dijadikan basis gerilya untuk perjuangan jangka panjang. Pimpinan Kepolisian Karesidenan Surakarta Saleh Sastranegara meminta bantuan kekuatan kepada pimpinan Jawatan Kepolisian Negara, menugaskan Mohammad Yasin sebagai kepala Mobile Brigade Besar wilayah
Jawa Timur. Selain itu menugaskan satu tim penyelidik untuk berangkat ke Surakarta dengan tujuan menumpas PKI di Madiun.

Tanggal 21 Desember 1948 Belanda melancarkan Agresi Militer II dengan sasaran memasuki Kota Surakarta. Serangan dilakukan dalam dua gelombang dari tanggal 7-9 Agustus 1949. Gelombang kedua tanggal 10 Agustus 1949, sesuai dengan perintah Let. Kol Slamet Riyadi. Pertahanan strategi yang diatur oleh Let Kol Slamet Riyadi membentuk Rayon-rayon dengan tujuan melemahkan pihak Belanda terhadap aksi Serangan Umum Empat Hari. Pertempuran berlangsung selama 4 hari 4 malam dan mencapai puncaknya pada tanggal 10 Agustus 1949. Pasukan TNI dan polisi bersama rakyat menghadapi serangan besarbesaran Belanda. Melalui bantuan kesatuan TNI dan Polisi. Laskar-laskar seperti Tentara Genie Pelajar, Tentara Pelajar, Hizbullah yang berada di dalam wilayah komando SWK 106 pimpinan Mayor Ahmadi memiliki tujuan untuk memperkuat dukungan melawan serangan Belanda.

\section{Daftar Referensi}

Arsip:

ANRI, Kepolisian Negara RI 1947-1949, No. 06.

ANRI, Arsip Kepolisian Negara 1947-1949, No. 72.

\section{Buku dan artikel:}

Bambang Purwanto, " Historiografi Dan Legitimasi Peran Sosial Politik Militer di Indonesia", dalam Edward L. Poelinggomang dan Suriadi Mappangara, Dunia Militer di Indonesia Keberadaan dan Peran Militer di Sulawesi, Yogyakarta: UGM Press, 2000. 
Bellamy, Richard, Teori Sosial Modern: Persepektif Itali, Jakarta: LP3ES, 1990.

Darsiti Soeratman, Kehidupan Dunia Kraton Surakarta 1830 - 1839, Yogyakarta: Taman Siswa, 1989.

Dwi Ratna Nurhajarini, “Dari

Tokubetsu Keisatsutai Ke Polisi Istimewa: Kepolisian Di

Surabaya", dalam Jurnal

Patrawidya .Vol. 12, No. 2, 2011.

Helius Sjamsudin, Metodologi Sejarah, Yogyakarta: Ombak, 2007.

Hugiono dan P.K. Poerwantana,

Pengantar Ilmu Sejarah, Jakarta: PT Rineka Cipta, 2002.

INKOPAK, 20 Tahun Perkembangan Angkatan Kepolisian Republik Indonesia, Jakarta: Mabes Polri, 1967.

Iwa Kusuma Sumantri, “Analisa

Tentang Peristiwa-Peristiwa disekitar Proklamasi Kemerdekaan Indoensia," Penelitian Sejarah, 1 Maret 1961. 